\title{
Supervisi Akademik Sebagai Upaya Meningkatkan Kompetensi Pedagogik Guru dalam Proses Pembelajaran di SMP Negeri 18 Mataram
}

\author{
H. Lalu Suwarno \\ SMP Negeri 18 Mataram, Kota Mataram - Provinsi NTB \\ *Corresponding Author. Email: suwarnolalu@gmail.com
}

\begin{abstract}
The purpose of this study is to improve the pedagogic competence of teachers in the learning process in the classroom through the implementation of academic supervision. This research uses the school action research method which is carried out in two cycles. The subjects of this study were 8 teachers of SMPN 18 Mataram. This research instrument uses observation sheets and documentation. The data analysis technique used descriptive analysis. The results of this study are: 1) the results of principal observations and teacher observations during the mentoring process have obtained an average score of 4.0,2) the results of the average value of teachers in the learning process reach $85 \%$ with an average score of 70,00 (good category). The results of the research in the first cycle of principal observations were average (3.80), teacher observations were averaged (3.00) and the results of academic supervision were on average score points (66.12). In cycle II, the average school supervisor's observations (4.40) with the percentage of achievement $(100 \%)$, the teacher's observations on the average (4.25) with the percentage of achievement $(100 \%)$ and the results of academic supervision in the target average value $(84,92)$ with the percentage of achievement $(100 \%)$. The conclusion obtained from the results of this study is that academic supervision can improve the pedagogic competence of teachers in the learning process in the classroom.
\end{abstract}

\begin{abstract}
Abstrak: Tujuan penelitian ini adalah untuk meningkatkan kompetensi pedagogik guru dalam proses pembelajaran di kelas melalui pelaksanaan supervisi akademik. Penelitian ini menggunakan metode penelitian tindakan sekolah yang dilaksanakan dalam dua siklus. Subyek penelitian ini adalah 8 guru SMPN 18 Mataram. Instrument penelitian ini menggunakan lembar observasi dan dokumentasi. Teknik analisis datanya menggunakan analisis deskriptif. Hasil penelitian ini adalah: 1) hasil observasi kepala sekolah maupun observasi guru selama proses pendampingan telah memperoleh skor rata-rata $\geq 4,0,2$ ) hasil nilai rata-rata guru dalam proses pembelajaran mencapai $\geq 85 \%$ dengan nilai rata-rata $\geq 70,00$ (kategori baik). Hasil penelitian pada siklus I obeservasi Kepala Sekolah rata-rata $(3,80)$, observasi guru rata-rata $(3,00)$ dan hasil supervise akademik di sasaran rata-rata nilai $(66,12)$. Pada siklus II observasi pengawas sekolah ratarata $(4,40)$ dengan presentase ketercapaian $(100 \%)$, observasi guru rata-rata $(4,25)$ dengan presentase ketercapaian $(100 \%)$ dan hasil supervisi akademik di sasaran rata-rata nilai $(84,92)$ dengan presentase ketercapaian (100\%). Kesimpulan yang diperoleh dari hasil penelitian ini adalah supervise akademik dapat meningkatkan kompetensi pedagogik guru dalam proses pembelajaran di kelas.
\end{abstract}

Article History

Received: 01-12-2021

Revised: 13-12-2021

Accepted: 24-12-2021

Published: 07-01-2022

\section{Key Words:}

Extensive Academic

Supervision, Pedagogic

Competence, Teachers,

Learning

\section{Sejarah Artikel}

Diterima: 01-12-2021

Direvisi: 13-12-2021

Disetujui: 24-12-2021

Diterbitkan: 07-01-2022

\section{Kata Kunci:}

Supervisi Akademik, Kompetensi Pedagogik, Guru, Pembelajaran

How to Cite: Suwarno, H. (2022). Supervisi Akademik Sebagai Upaya Meningkatkan Kompetensi Pedagogik Guru dalam Proses Pembelajaran di SMP Negeri 18 Mataram. Jurnal Paedagogy, 9(1), 150-158. doi:https://doi.org/10.33394/jp.v9i1.4682

\section{Pendahuluan}

Salah satu kompetensi yang harus dimiliki dan dikuasai kepala sekolah sebagai supervisor pembelajaran di kelas yaitu supervisi akademik. Oleh karena itu, kepala sekolah 
harus memahami konsep-konsep supervisi akademik agar dapat melaksanakan tugas sebagai supervisor secara professional sehingga bermuara kepada peningkatan kemampuan profesional guru yang menjadi tanggung jawab sebagai kepala sekolah (Purnamaraya, 2019; Suginam, 2019). Apabila kepala sekolah dan guru mata pelajaran yang dibina mampu berkolaborasi dan berinteraksi secara sinergi maka akan berdampak terhadap peningkatan mutu pembelajaran dalam proses pembelajaran dikelas senyatanya. Dan ini membuktikan bahwa kepala sekolah sebagai mitra kerja dengan guru di sekolah binaanya dalam proses pembelajaran.

Surpervisi akademik harus secara langsung mempengaruhi keadaan lingkungan perilaku guru dalam mengelola kelas pada proses pembelajaran dimana guru secara langsung maupun tidak langsung merubah mindset dalam menyampaikan materi pembelajaran pada kegiatan pendahuluan, kegiatan inti, maupun kegiatan penutup. Kompetensi guru yang mampu merubah mainset terlihat pada tahap eksplorasi, elaboarasi, konfirmasi. Guru harus mampu membangkitkan motivasi belajar peserta didik, dan mengedepankan proses elaborasi sehingga prilaku peserta didik yang hendak diukur dapat terlihat dan muncul selama proses pembelajaran dengan mengambil prinsip belajar peserta didik aktif (Sudiarti, 2017; Rusmiarsi, 2017). Tingkat kemampuan, kebutuhan, minat, dan kemataangan profesional serta karakteristik personal guru harus dijadikan dasar pertimbangan dalam pengembangan dan mengimplementasikan program supervisi akademik khususnya dalam proses pembelajaran dikelas senyatanya (Kamaruddin, 2021; Jamilan, 2017).

Kondisi nyata yang terjadi di SMP Negeri 18 Mataram terhadap 8 (delapan) guru sasaran sebelum diadakan tindakan dalam upaya merubah mainset guru dari pola belajar guru aktif (guru sentris) ke pola belajar peserta didik aktif dapat dilihat pada data sebagai berikut.

Tabel 1. Data Pola Mengajar Guru

\begin{tabular}{|c|l|c|}
\hline No & \multicolumn{1}{|c|}{ Pola Mengajar di Kelas } & Jumlah guru \\
\hline 1. & $\begin{array}{l}\text { Mengajar dengan mengedepankan pada belajar } \\
\text { peserta didik aktif }\end{array}$ & 1 \\
\hline 2. & Mengajar dengan memperbanyak tugas-tugas & 2 \\
\hline 3. & Mengajar dengan ceramah (guru sentris) & 3 \\
\hline 4. & Mengajar dengan memberikan catatan dan tugas & 2 \\
\hline \multicolumn{2}{|c|}{ Jumlah } & $\mathbf{8}$ \\
\hline
\end{tabular}

Faktor penyebab kondisi pembelajaran dikelas yang masih belum sesuai dengan Permen No. 41 Tahun 2007 tentang standar proses ini antara lain :1) Pembiasaan guru yang sudah membudaya, 2) Konpetensi guru dalam proses pembelajaran dikelas senyatanya masih rendah, 3) Guru kurang mempersiapkan perangkat pembelajaran sebelum masuk di kelas, 4) Guru belum mampu merubah mainset cara mengajar kearah pembelajaran yang berbasis peserta didik aktif, 5) Alaasan-alasan lain yang bersifat konvensional seperti guru yang berpendapat yang penting mengajar dengan metode apa saja yang tidak terlalu ruet dan materi pembelajaran selesai walaupun belum tuntas.

Dampak dan akibat yang tejadi adalah; 1) Proses pembelajaran terkesan di monopoli oleh keaktifan guru berceramah yang diselingi marah-marah, mematahkan semangat peserta didik, 2) Guru menjadi raja dikelas dalam proses pembelajaran, apa katanya guru itulah yang paling benar, peserta didik duduk manis menerima penjelasan dari guru tanpa melihat benar dan salah, 3) Proses pembelajaran kurang bermakna bagi perkembangan pengetahuan, sikap, 
dan ketrampilan bagi peserta didik, 4) Proses pembelajaran tidak kondusif yang mengakibatkan rendahnya motivasi dan hasil belajar peserta didik, 5) Proses pembelajaran peserta didik tidak mampu mencapai kriteria ketuntasan minimal (KKM) yang telah ditetapkan, dan 6) Akibat yang paling patal peserta didik kurang simpatik terhadap guru-guru mata pelajaran yang mengakibatkan mutu pendidikan dan gaung SMP Negeri 18 Mataram di mata masyarakat kurang di minati.

Solusi yang bisa dilakukan oleh kepala sekolah selaku peneliti sebenarnya banyak antara lain : 1) Mengefektifkan MGMP bagi guru sasaran, 2) Mengadakan workshop terkait dengan penyusunan RPP yang baik dan benar dan tata cara mengajar yang mengarah kepada kegiatan peserta didik aktif, 3) Mengadakan microteaching dan riilteaching dalam proses pembelajaran yang mengarah kepada kegiatan eksplorasi, elaboarasi dan konfirmasi, dan 4) Mengefektifkan supervisi dalam proses pembelajaran bagi guru sasaran yang dititikberatkan pada tata cara mengajar yang baik dan benar di kelas senyatanya. Dengan mengefektifkan pelaksanaan supervisi akademik yang terfokus pada kegiatan proses pembelajaran dikelas diharapkan mampu meningkatkan konpetensi guru sasaran di SMP Negeri 18 Mataram dalam mengelola kegiatan pembelajaran kearah peserta didik aktif. Dari beberapa solusi tersebut, alternatif yang paling strategis dan bisa merangkum dari semua solusi adalah dengan mengefektifkan peaksanaan supervisi akademik yang tefokus pada pelaksanaan proses pembelajaran di kelas senyatanya. Adapun tujuan penelitian ini adalah untuk meningkatkan kompetensi pedagogik guru SMP Negeri 18 Mataram dalam proses pembelajaran di kelas melalui pelaksanaan supervisi akademik.

\section{Metode Penelitian}

Penelitian Tindakan Sekolah (PTS) ini dilaksanakan di SMP Negeri 18 Mataram. Skenario supervisi akademik dalam penelitian ini adalah, langkah yang diambil pada kegiatan supervisi akademik dengan mengumpulkan 8 (delapan) guru sasaran SMP Negeri 18 Mataram untuk diberikan penjelasanan tentang supervisi akademik yang difokuskan pada kegiatan pembelajaran dikelas senyatanya. Dalam pelaksanaannya, kegiatan supervisi akademik melalui "siklus", dimana setiap siklus ditetapkan 2 (dua) kali pertemuan Pertemuan I berupa pendampingan klasikal, sedangkan pertemuan ke 2 pengamatan dalam proses pembelajaran dikelas senyatanya. Untuk mendapatkan gambaran yang jelas tentang skenario pelaksanaan tindakan dalam kegiatan supervisi akademik ini dapat digambarkan sebagai berikut:

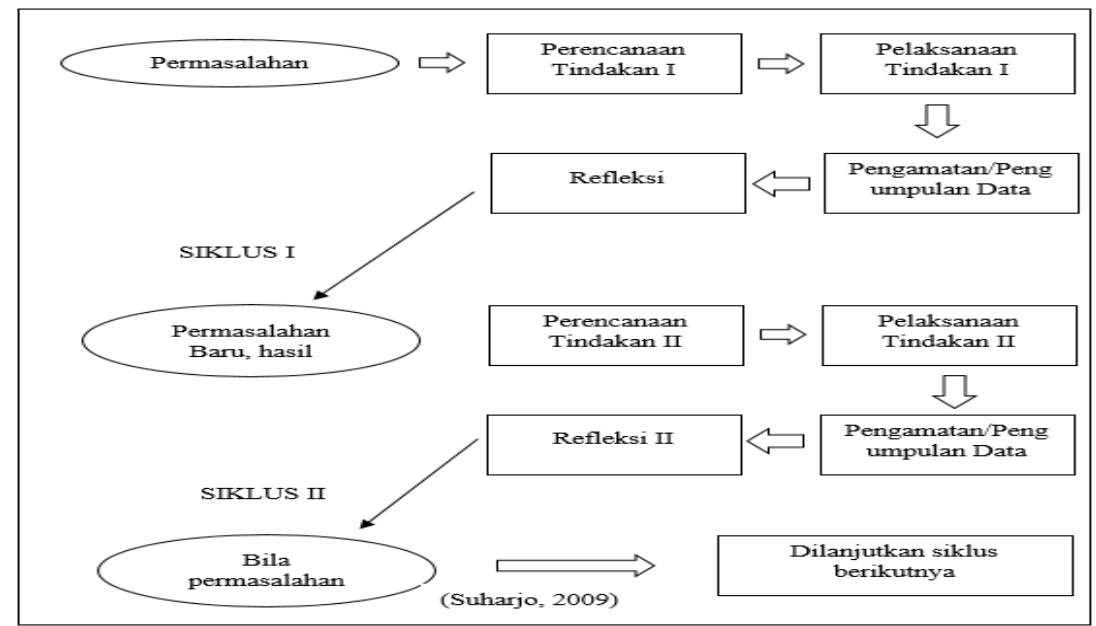

Gambar 1. Skenario Tindakan 
Instrumen yang digunakan dalam penelitian ini adalah lembar observasi dan dokumentasi. Teknik analisis data penelitian ini menggunakan analisis deskriptif. Adapaun indikator Keberhasilan penelitian ini adalah (1) Hasil observasi Kepala sekolah maupun observasi guru selama proses pendampingan telah memperoleh skor rata-rata $>4,0$ (kategori baik/kategori aktif), dan (2) Hasil nilai rata-rata guru dalam proses pembelajaran mencapai $>85 \%$ dengan mlai rata-rata 70,00 (kategori baik).

\section{Hasil Penelitian dan Pembahasan Deskripsi Siklus I \\ Tahap Perencanaan}

Dalam penyusunan materi tentang supervisi akademik mengalami kendala yaito peneliti kekurangan literatur sebagai rujukan, dampaknya terjadi keterlambatan dalam pelaksanaannya, solusi yang dilakukan oleh peneliti a) berkonsentrasi dengan Kepala pembimbing, b) mencari materi terkait dengan supervisi akademik di perpustakaan maya. (internet), hasilnya peneliti dapat menyelesaikan penyusunan materi pendampingan klasikal yang telah disampaikan pada tahap pelaksanaan. Dalam persiapan skenario tindakan selama pendampingan klasikal juga mengalami kendala yaitu dalam hal pemilihan strategi yang tepat bagi guru sasaran sehingga pelaksanaan pendampingan kurang lancar, dampaknya adalah terlambatnya penentuan skncario, solusi yang dilakukan oleh peneliti meminta petunjuk kepada Kepala pembimbing strategi apa yang tepat dan dapat di paparkan pada skenario pendampingan Setelah mendapatkan petunjuk akhirnya skenario pendampingan terhadap 8 (delapan) guru sasaran SMP Negeri 18 Mataram dapat diatasi.

Dalam penyusunan instrumen observasi Kepala sekolah dan instrumen observasi peserta pendampingan juga mengalami kendala yaitu dalam memilih/menentukan item yang harus muncul dalam pengamatan pada saat Kepala sekolah melakukan pendampingan klasikal maupun item yang akan digunakan dalam pengamatan terhadap guru di kelas senyatanya. Hal ini berakibat macetnya dalam penyusunan instrumen. Solusi yang dilakukan adalah meminta petunjuk kepada Kepala pembimbing Setelah mendapatkan bimbingan dan arahan akhirnya instrumen pengamatan terhadap kinerja Kepala sekolah maupun kinerja guru dapat diatasi.

Dalam penentuan jadwal supervisi akademik bagi 8 (delapan) guru sasaran dalam proses pembelajaran di kelas senyatanya mengalami kendala yaitu karena rata-rata guru mengajar di kelas dalam waktu yang bersamaan akibatnya jadwal tidak bisa tersusun sesuai dengan kesiapan guru Solusi yang dilakukan oleh peneliti yaitu dengan mengumpulkan ke 8 (delapan) guru sasaran untuk diminta kesanggupan, jam berapa, dan hari apa Setelah berkolaborasi dengan ke 8 (delapan) guru sasaran jadwal supervisi akademik dalam proses pembelajaran di kelas dapat diselesaikan dengan baik. Kegiatan selanjutnya peneliti menetukan penyususnan pedoman analisa data hasil observasi Kepala sekolah, observasi guru dalam proses pembelajran di kelas dan hasil supervisi akademik dari ke 8 (selapan) guru juga mengalami kendala yaitu untuk memilih rumus yang tepat dan akurat serta cepat dianalisis. Dampaknya sampai batas waktu yang telah ditetapkan pedoman hasil observasi dan hasil supervisi akademik belum selesai. Solusi peneliti minta petunjuk dari Kepala pembimbing untuk membantu menyelesaikan masalah. Setelah diberikan penjelasan rinci akhirnya peneliti berhasil menyusun pedoman analisa data hasil observasi dan hasil supervisi akademik dengan benar.

\section{Tahap Pelaksanaan Pertemuan 1}


Dalam melaksanakan pendampingan klasikal tentang perlunya pendampingan dan penyampaian materi tentang supervisi akademik yang kegiatan nyatanya menjelaskan bagaimana cara mangajar yang baik dan benar sesuai dengan instrument yang telah ditetapkan, serta pelaksanaan Tanya jawab kepada peserta mengalami hambatan yaitu yang seharusnya pukul 08.00 dimulai tetapi karena sebagian guru ada yang masih ada yang mangajar, ada yang memberikan tugas kepada peserta didik yang berakibat molornya pelaksanaan pendampingan klasikal. Solusinya peneliti mengundurkan waktu pelaksanaan +15 menit, setelah semua guru berkumpul baru dilaksanakan pendampingan klasikal. Hasilnya semua rencana dapat terlaksana tanpa menambah waktu yang telah disiapkan.

\section{Pertemuan II}

Pelaksanaan supervisi dalam proses pembelajaran di kelas senyatanya dilakukan sesuai jadwal yang telah disepakati. hari pertama supervisi kelas yaitu Senin tanggal 4 Februari 2019 di kelas X mata pelajaran Bahasa Indonesia jam 3-4 atas nama Dra. Hj. Pratini. hambatan yang dialami oleh peneliti, guru yang bersangkutan terlambat masuk kelas \pm 10 menit, factor penyebabnya yang bersangkutan baru saja mengajar di kelas lain yang berdampak pada kondisi kelas agak gaduh. Solusi yang dilakukan oleh peneliti yaitu dengan memanggil guru yang bersangkutan untuk segera masuk kelas dan hasilnya proses pembelajaran berjalan lancar. Dan pelajaran ke 5-6 di Kelas XI mata pelajaran Bahasa Indonesia atas nama Adriyanti, S.Pd dalam melakukan supervisi akademik dalam proses pembelajaran tidak mengalami hambatan yang mengganggu pelaksanaan pembelajaran. Selanjutnya peneliti mensupervisi di Kelas X pada jam pelajaran 7-8 mata pelajaran Bahasa Inggris yang di ampu oleh Nurminah, S.Pd. dalam pelaksanaan supervisi tidak ada hambatan, artinya berjalan lancar seperti yang diharapkan.

Hari ke dua Selasa tanggal 5 Februari 2019, peneliti memasuki kelas X pada jam ke 5. 6 dengan gurunya Dheni Sulistiyaningsih, S.Pdmata pelajaran Matematika. Dalam pelaksanaan supervisi di kelas ini berjalan lancar dari awal hingga berakhir proses pembelajaran. Pada pelajaran ke 7-8 peneliti masuk di kelas X yaitu mata pelajaran Bahasa Jerman yang diampu oleh Maisun, S.Pd kegiatan supervisi di kelas ini mengalami sedikit permasalahan yaitu pada saat peneliti mau massuk di kelas tiba-tiba ada tamu yang harus dilayani selama 15 menit. Dampaknya pada kegiatan pendahuluan peneliti tidak bisa mengamati secara utuh, solusinya peneliti mewawancarai siswa yang bersangkutan setelah selesai proses pembelajaran, dan hasilnya semua kegiatan pendahuluan dapat diberikan skor/nilai semestinya. Pada hari ketiga Rabu tanggal 6 Februari 2019 peneliti mensupervisi dua guru mata pelajaran masing-masing adalah Fery Mulyadi, S.Pddi kelas X jam ke 1-2 dengan mata pelajaran Kimia dan pada jam ke 5-6 di kelas X7 mata pelajaran Fisika oleh Ika Yulianti, S.P. pelaksanaan supervisi berjalan lancar tidak ada hambatan yang berarti. Pada hari ke keempat Jumat tanggal 7 Februar 2019 peneliti mensupervisi di kelas XII mata pelajaran Biologi pada jam pelajaran 5-6. Pelaksanaan supervisi mengalami hambatan yaitu molor 15 menit yang Dampaknya pada mata pelajaran Matematika ini tersita waktunya \pm 15 menit. Solusi yang dilakukan oleh peneliti yaitu dengan memberikan pengarahan kepada guru yang bersangkutan agar dalam proses pembelajaran lebih diefektifkan. Dan hasilnya materi pelajaran yang telah direncanakan pada hari itu selesai sesuai RPP yang direncanakan.

\section{Tahap Pengamatan/Pengumpulan Data}

Pengamatan/observasi Kepala sekolah oleh pengawas pembimbing selaku observers pada kegiatan pendampingan klasikal (pertemuan I) berjalan lancar, artinya tidak ada kendala hasil skor rata-rata yang diraih oleh Kepala sekolah/peneliti $(3,80)$ kategori cukup dari indikator keberhasilan yang diharapkan yaitu $>4,00$ (kategori aktif). Hal ini disebabkan 
karena kepala sekolah dalam melaksanakan pendampingan masih belum optimal, dan masih belum menguasai materi tentang supervisi akademik yang kegiatan nyatanya upaya bagaimana menjadi guru yang mampu mengajar di kelas yang baik dan benar. Dalam pendampingan tentang butir-butir instrumen pengamatan ketika guru sedang melaksanakan proses pembelajaran juga masih belum menguasai. Sementara itu hasil observasi guru oleh peneliti selama proses pendampingan klasikal, dilihat dari aktifitas dari ke enam guru kelas memperoleh rata-rata $(3,00)$ kategori cukup dari indikator keberhasilan yang direncanakan yaitu $>4,00$ (kategori aktif).

Pada pertemuan kedua yakni pelaksanaan supervisi akademik yang terfokus pada pelaksanaan proses pembelajaran di kelas senyatanya dapat dijelaskan sebagai berikut 1) dari ke 8 (delapan) guru sasaran baru satu orang guru yang dinyatakan tuntas dengan indikator 2 $70,00$ (baik) yaitu atas nama Mahsun, S.Pd, dengan nilai rata-rata $(78,57), 2)$ perolehan nilai rata-rata hasil supervisi akademik dari 8 (delapan) guru Sasaran peroleh hasil $(66,12)$ dengan presentase ketuntasan $12,50 \%, 3$ ) peneliti mengadakan perbaikan/penyempurnaan berupa bimbingan individual dan bimbingan secara klasikal.

\section{Tahap Refleksi}

Setelah semua perolehan data dianalisis dan di cocokkan dengan indikator keberhasilan, diperoleh data sebagai berikut:

Tabel 2. Data Perolehan Hasil Siklus I

\begin{tabular}{|c|l|c|c|c|}
\hline No & \multicolumn{1}{|c|}{ Jenis Kegiatan } & $\begin{array}{c}\text { Indikator } \\
\text { Keberhasilan }\end{array}$ & Rata-rata & Keterangan \\
\hline 1. & Hasil Observasi Kepala Sekolah & $>4,00$ & 3,80 & Belum Tuntas \\
\hline 2. & Hasil Observasi Guru & $>4,00$ & 3,00 & Belum Tuntas \\
\hline 3. & Hasil Supervisi Akademik & $>70,00$ & 66,12 & Belum Tuntas \\
\hline
\end{tabular}

\section{Deskripsi Siklus II \\ Tahap Perencanaan}

Pada tahapan ini peneliti telah memperbaiki semua kekurangan dan kesalahankesalahan yang dilakukan pada siklus I Pada siklus II semua perencanaan tidak ada hambatan artinya berjalan sesuai dengan rencana yang telah ditetapkan. Kegiatan-kegiatan nyata yang dilakukan tidak ada hambatan adalah 1) penyusunan materi pendampingan berkaitan dengan supervisi akademik, 2) penetapan/penyusunan skenario tindakan, 3) penyusunan instrumen observasi, 4) penentuan jadwal kegiatan, dan 5) penyusunan pedoman analisa data.

\section{Tahap Pelaksanaan \\ Pertemuan I}

Peneliti melakukan pendampingan klasikal dengan mengoptimalkan tindakan nyata terutama kesalahan-kesalahan/kekurangan yang terjadi pada siklus I lebih dioptimalkan, sehingga dalam pelaksanaan pendampingan pada siklus II ini berjalan lancar tanpa hambatan yang berarti. Jadwal yang direncanakan dilaksanakan sesuai rencana dan tidak ada lagi guru yang terlambat dan kegiatan pendampingan berjalan tepat waktu. Semua guru aktif bertanya/Tanya jawab yang menyebabkan suasana kekeluargaan. Semakin terjalin dengan erat dan menunjukkan etika yang sangat membanggakan.

\section{Pertemuan II}

Pelaksanaan supervisi akademik di kelas senyatanya berjalan sesuai jadwal yang telah ditetapkan. Semua guru mengajar di kelas tepat waktu. Perolehan hasil dapat dipaparkan dengan data sebagai berikut: 
Tabel 3. Data Hasil Supervisi Akademik Siklus I

\begin{tabular}{|c|l|c|l|}
\hline No & \multicolumn{1}{|c|}{ Nama Guru } & Nilai Akhir & Keterangan \\
\hline 1. & Dra. Hj. Pratini & 89,29 & Tuntas \\
\hline 2. & Makmun, S.Pd & 83,93 & Tuntas \\
\hline 3. & Nurminah, S.Pd & 81,25 & Tuntas \\
\hline 4. & Dheni Sulistiyaningsih, S.Pd & 83,93 & Tuntas \\
\hline 5. & Maisun, S.Pd & 88,39 & Tuntas \\
\hline 6. & Fery Mulyadi, S.Pd & $\mathbf{8 4 , 4 8}$ & Tuntas \\
\hline 7. & Ika Yulianti, S.P & $\mathbf{8 3 , 6 2}$ & Tuntas \\
\hline 8. & Kamariah, S.Pd & $\mathbf{8 4 , 4 8}$ & Tuntas \\
\hline \multicolumn{2}{|c|}{ Rata -rata / \% Ketuntasan } & $\mathbf{8 4 , 9 2}$ & $\mathbf{1 0 0} \%$ \\
\hline
\end{tabular}

\section{Tahap Pengamatan/Pengumpulan Data}

Hasil pengamatan penampilan Kepala sekolah/peneliti yang dilakukan oleh observer, maupun hasil pengamatan guru selama proses pendampingan oleh pengawas pembimbing diperoleh data sebagai berikut:

Tabel 4. Data Hasil Observasi Siklus II

\begin{tabular}{|c|c|c|c|c|}
\hline No & Jenis Kegiatan & $\begin{array}{c}\text { Indikator } \\
\text { Keberhasilan }\end{array}$ & $\begin{array}{c}\text { Perolehan } \\
\text { Skor } \\
\text { Rata-rata }\end{array}$ & Keterangan \\
\hline 1. & Hasil Observasi Kepala Sekolah & $>4,00$ & 4,40 & Tuntas \\
\hline 2. & Hasil Observasi Guru & $>4,00$ & 4,25 & Tuntas \\
\hline \multicolumn{2}{|c|}{$\%$ Ketuntasan } & & $\mathbf{1 0 0} \%$ & Tuntas \\
\hline
\end{tabular}

Sebagaimana paparan data diatas dapat dijelaskan bahwa selama proses pengamatan kegiatan pendampingan berjalan lancar. Perolehan hasil supervisi akademik pada siklus II memperoleh nilai rata-rata $(84,92 /$ kategori A) dan dinyatakan $100 \%$ tuntas. Hasil ini merupakan dampak positif dari upaya mengoptimalkan tindakan pelaksanaan supervisi akademik dikelas senyatanya.

\section{Tahap Refleksi}

Hasil observasi Kepala sekolah, guru peserta pendampingan serta hasil supervisi akademik di kelas senyatanya telah melampaui indikator keberhasilan yang telah ditetapkan. Penelitian Tindakan Sekolah (PTS) dinyatakan telah berhasil dan dihentikan pada siklus II, dengan perolehan peningkatan sebagai berikut:

Tabel 5. Data Perolehan Hasil Siklus II

\begin{tabular}{|c|l|c|c|c|c|}
\hline No & \multicolumn{1}{|c|}{ Jenis Kegiatan } & $\begin{array}{c}\text { Indikator } \\
\text { Keberhasilan }\end{array}$ & $\begin{array}{c}\text { Rata- } \\
\text { rata }\end{array}$ & \% & Keterangan \\
\hline 1. & Hasil Observasi Kepala Sekolah & $>4,00$ & 4,40 & $100 \%$ & Tuntas \\
\hline 2. & Hasil Observasi Guru & $>4,00$ & 4,25 & $100 \%$ & Tuntas \\
\hline 3. & Hasil Supervisi Akademik & $>70,00$ & 84,92 & $100 \%$ & Tuntas \\
\hline
\end{tabular}

Peneliti memberikan reward/penghargaan kepada semua guru peserta pendampingan atas hasil yang diraih dan mampu memperoleh nilai diatas rata-rata indikator yang telah ditetapkan. Perbaikan dan penyempurnaan kegiatan tidak perlu dilakukan karena penelitian telah berhasil mencapai indikator yang telah ditetapkan. Penelitian Tindakan Sekolah (PTS) dinyatakan "BERHASIL" dan dihentikan pada siklus II. Adapun hasil penelitian ini sejalan dengan penelitian Purnamaraya (2021), Suginam (2019), dan Kamarudin (2021) yang menjelaskan bawah kemampuan, kompetensi pedagogik dan kemataangan profesional serta 
karakteristik personal guru dapat meningkat dengan mengimplementasikan program supervisi akademik secara berkelanjutan.

\section{Kesimpulan}

Kesimpulan yang diperoleh dari hasil penelitian ini adalah: 1) hasil observasi kepala sekolah maupun observasi guru selama proses pendampingan telah memperoleh skor rata-rata $\geq 4,0$, 2) hasil nilai rata-rata guru dalam proses pembelajaran mencapai $\geq 85 \%$ dengan nilai rata-rata $\geq 70,00$ (kategori baik). Hasil penelitian pada siklus I obeservasi Kepala Sekolah rata-rata $(3,80)$, observasi guru rata-rata $(3,00)$ dan hasil supervise akademik di sasaran rata-rata nilai $(66,12)$. Pada siklus II observasi pengawas sekolah rata-rata $(4,40)$ dengan presentase ketercapaian $(100 \%)$, observasi guru rata-rata $(4,25)$ dengan presentase ketercapaian $(100 \%)$ dan hasil supervisi akademik di sasaran rata-rata nilai $(84,92)$ dengan presentase ketercapaian $(100 \%)$. Kesimpulan yang diperoleh dari hasil penelitian ini adalah supervise akademik dapat meningkatkan kompetensi pedagogik guru dalam proses pembelajaran di kelas.

\section{Saran}

Saran yang dapat disampaikan berdasarkan hasil penelitian ini adalah; (!) Bagi Kepala Sekolah Sejawat, diharapkan untuk melakukan supervisi akademik secara efektif, karena dengan mengefektifkan supervisi akademik dapat meningkatkan kompetensi guru dalam proses pembelajaran di kelas senyatanya sesuai dengan mata pelajaran yang diajarkan dan menjadi tanggung jawabnya masing-masing. (2) Bagi Guru Sasaran, agar senantiasa: (a) Merencanakan kegiatan pembelajaran dengan sebaik-baiknya dengan strategi pembelajaran yang mengarah ke peserta didik aktif, kreatif, inovatif, dan demokratif. (b) Melakukan proses pembelajaran sesuai dengan skenaro yang telah direncanakan dengan baik, tanggung jawab, bersunggung-sungguh demi peningkatan prestasi belajar peserta didik sesuai dengan bidang studi/mata pelajaran yang menjadi tanggung jawabnya.

\section{Daftar Pustaka}

Alauddin. (2019). Supervisi Akademik Kepala Sekolah. https://www.academia.edu/6747/SUPERVISI_OLEH_KEPALA SEKOLAH. Diambil tanggal 8 januari 2019. Pukul 09.36 Wita.

Cahya Wirawan. (2012). Peningkatan Kompetensi Guru Sasaran Dalam Pemanfaatan Media Pembelajaran Melalui Mentoring, Jakarta: Jurnal PTK Dikmen.

Ditjen PMPTK Depdiknas.(2006). Supervisi Akademik dalam peningkatan profesionalisme guru. Kompetensi Supervisi Kepala Sekolah Pendidikan Dasar. Direktorat Tenaga Kependidikan Ditjen PMPTK Depdiknas.

Glickman, C.D., Gordon, S.P., and Ross-Gordon, J.M. (2007). Supervission and Instructional Leadership A Development Approach. Seventh Edition. Boston: Perason.

Jamilan, J. (2017). Meningkatkan Kompetensi Guru Kelas dalam Proses Pembelajaran Melalui Supervisi Akademik di SD Negeri 4 Mataram. Jurnal Kependidikan: Jurnal Hasil Penelitian dan Kajian Kepustakaan di Bidang Pendidikan, Pengajaran dan Pembelajaran, 3(2). doi:https://doi.org/10.33394/jk.v3i2.675

Kamaruddin, H. (2021). Upaya Meningkatkan Kompetensi Guru SMK Negeri 4 Gowa dalam Melaksanakan Proses Pembelajaran di Kelas Melalui Program Supervisi. Jurnal Paedagogy, 8(3), 414-421. doi:https://doi.org/10.33394/jp.v8i3.3894

Mulyasa. (2007). Kurikulum Tingkat Satuan Pendidikan, Bandung: Ramaja Rosda Karya. 
Nana Sujana. (2009). Pendidikan Tingkat KePenelitian Konsep dan Aplikasinya Bagi Peneliti Sekolah, Jakarta: LPP Bina Matra.

Purnamaraya, S. (2019). Upaya Meningkatkan Kompetensi Guru Kelas dalam Proses Pembelajaran Berdasarkan Kurikulum 2013 Melalui Supervisi Akademik di SD $\begin{array}{llll}\text { Negeri } & 45 & \text { Mataram. Jurnal } \quad \text { Paedagogy, } & 6(2),\end{array}$ doi:https://doi.org/10.33394/jp.v6i2.2531

Robbins, S.P, (2008). The Truth About Managing People. Second Edition. Upper Sadle River, New Jersey: Pearson Education, Inc.

Rusmiarsi, R. (2017). Meningkatkan Kompetensi Guru dalam Proses Pembelajaran Berdasarkan Kurikulum 2013 Melalui Supervisi Akademik di SD Negeri 40 Ampenan. Jurnal Kependidikan: Jurnal Hasil Penelitian dan Kajian Kepustakaan di Bidang Pendidikan, Pengajaran dan Pembelajaran, 3(2). doi:https://doi.org/10.33394/jk.v3i2.680

Sudiarti, D. (2017). Upaya Meningkatkan Kompetensi Guru Kelas dalam Proses Pembelajaran Melalui Supervisi Akademik di SDN 9 Cakranegara. Jurnal Kependidikan: Jurnal Hasil Penelitian dan Kajian Kepustakaan di Bidang Pendidikan, Pengajaran dan Pembelajaran, 3(1). doi:https://doi.org/10.33394/jk.v3i1.463

Suginam, A. (2019). Upaya Meningkatkan Kompetensi Guru Kelas dalam Proses Pembelajaran Melalui Supervisi Akademik di SD Negeri 4 Mataram. Jurnal Paedagogy, 6(2), 41-48. doi:https://doi.org/10.33394/jp.v6i2.2530

Suharjono. (2009). Melaksanakan Sekolah Sebagai Kegiatan Penelitian Tindakan Sekolah Sebgai Kegiatan Pengembangan Profesi Penelitian Sekolah, Jakarta: Bumi Aksara. 